\title{
Limonium duriusculum (de Girard) Kuntze Exhibits Anti-inflammatory Effect Via NF-kB Pathway Modulation
}

Meriem Hadjer Hamadou ${ }^{1}$

https://orcid.org/0000-0001-6225-1014

Messaoud Kerkatou ${ }^{2}$

https://orcid.org/0000-0002-3071-603X

Chiara Zucal ${ }^{3}$

https://orcid.org/0000-0001-8428-2495

Alessandra Bisio ${ }^{3}$

https://orcid.org/0000-0002-3326-1923

\section{Alessandro Provenzani ${ }^{3}$}

https://orcid.org/0000-0003-1652-3415

\author{
Alberto Inga ${ }^{3}$ \\ https://orcid.org/0000-0002-8767-1637
}

Ahmed Menad ${ }^{1}$

https://orcid.org/0000-0002-5851-8123

Samir Benayache ${ }^{2}$

https://orcid.org/0000-0003-2298-2466

Fadila Benayache ${ }^{2}$

https://orcid.org/0000-0002-2282-6343

Souad Ameddah ${ }^{1 *}$

https://orcid.org/0000-0001-9115-6972

${ }^{1}$ University of Frères Mentouri Constantine1, Faculty of Life Sciences and Nature, Laboratory of Biology and Environment Constantine, Algeria; ${ }^{2}$ University of Frères Mentouri Constantine1, Development of Natural Resources, Bioactive Molecules, Physico-chemical and Biological Analyzes (VARENBIOMOL), Constantine, Algeria; ${ }^{3}$ University of Trento, Department CIBIO, Trento, Italy.

Editor-in-Chief: Paulo Vitor Farago

Associate Editor: Daniel Fernandes

Received: 2020.03.28; Accepted: 2020.10.07.

*Correspondence: amedsouad@yahoo.fr; Tel.: +213-666768290. (S.A.)

\section{HIGHLIGHTS}

- L. duriusculum n-BuOH extract reduces inflammatory responses both in vitro and in vivo.

- L. duriusculum n-BuOH extract inhibits NF-kB-dependent transcriptional responses.

- L. duriusculum n-BuOH extract decreases the expression of TNF- $\alpha$ and IL-6 genes.

Abstract: Limonium duriusculum is used in folk medicine to treat inflammatory disorders and has gained attention due to its richness in apigenin. The present investigation was performed to evaluate and confirm its anti-inflammatory properties, in cell lines and animal models. The potential anti-inflammatory properties of $n$ butanol $(n-\mathrm{BuOH})$ extract of $L$. duriusculum $(\mathrm{BEL})$ and isolated apigenins were examined on NF-KB transcriptional activity in TNFa- or LPS-stimulated cells, and on in vivo acute inflammatory models (carrageenan induced paw edema and peritonitis). BEL treatment was able to inhibit the activity of an NF-KB reporter gene in HCT116 cells both in the absence and in the presence of exogenous TNFa, used as NF-KB pathway inducer. This anti-inflammatory effect was even more potent compared to Apigenin (APG1) and was confirmed using monocyte-derived THP-1 cells treated with LPS to stimulate NF-kB-dependent transcription of IL-6 and TNF $\alpha$ mRNAs. Apigenin7-O- $\beta-(6$ "-methylglucuronide) (APG2) was instead inactive both in HCT116 and THP-1 cells. BEL (oral, $200 \mathrm{mg} / \mathrm{kg}$ ) led to paw swelling inhibition, vascular permeability and 
peritoneal leukocyte and PN migration diminution. Apigenins (intraperitoneal, APG1, APG2: $20 \mathrm{mg} / \mathrm{kg}$ ) also evoked a significant anti-edema effect, early vascular permeability and leukocyte influx reduction. Collectively, this study demonstrates for the first time the effectiveness of $L$. duriusculum to inhibit NF-KBdependent transcriptional responses in HCT116 and THP-1 cells. In vivo studies also established that $L$. duriusculum possesses a potential anti-inflammatory effect, confirm its traditional, empirical use, that could be attributed to its richness in apigenin.

Keywords: anti-inflammatory activity; Limonium duriusculum; Apigenin derivatives; $n$-BuOH extract; THP1; NF-kB; Immunomodulation.

\section{INTRODUCTION}

Herbal remedy is a more efficient and less costly substitute to synthetic compounds which have restrictions and are ineffective in the cure of chronic diseases [1]. Medicinal plants have long been used to treat chronic diseases such as cancer, neurodegeneration and diabetes [2]. Limonium duriusculum (Girard) Kuntze or Limonium duriusculum Fourr. [synonyms: Statice companyonis (Gren. \&Billot) O.Bolòs, Vigo, Masalles\&Ninot; Limonium thiniense (Erben); Statice duriuscula (Girard); Limonium duriusculum subsp. companyonis; Limonium duriusculum subsp. Thiniense (Erben) O.Bolòs, Vigo, Masalles\&Ninot; Limonium confusum subsp. duriusculum (Girard) P.Fourn. and other names [3-8]] is a plant belonging to the Plumbaginaceae family and grows along the western area of the Mediterranean. Historically the aforementioned herb is known to be used in folk and modern medicine by local populations to treat allergies [9]. As reported previously, it contains numerous kinds of active chemical compounds. Apigenin and apigenin7-O- $\beta$-(6"-methylglucuronide) were accumulated in this herb, to more than $1.6 \mathrm{~g}$ and $1.1 \mathrm{~g}$ per $\mathrm{kg}$ of air-dried plant material, respectively. Two newly identified flavones named duriusculin $A$ and duriusculin $B$ as well as six other flavones were also present [9].

In a previous study it was revealed that $L$. duriusculum exerts anti-oxidant activities [9]. Moreover, it was found recently that the $n$-butanolic extract of aerial parts of $L$. duriusculum had significant anti-proliferative, growth inhibitory and anti-tumor activities in HCT116 p53 wild type cells [10]. Accordingly, the biological effects of extracts from this plant havenot yet comprehensively addressed in the literature.

The focus of the current study was given on the examination of the in vitro and in vivo anti-inflammatory activities of the $n-\mathrm{BuOH}$ extract of $L$. duriusculum and its major constituents apigenin and apigenin7-O- $\beta-(6 "-$ methylglucuronide) on human cell lines and animal models. To the best of the authors' knowledge, these properties have not yet been investigated in the literature.

\section{MATERIAL AND METHODS}

Dimethyl Sulfoxide (DMSO) was purchased from local pharmacy and produced by Pharco Pharmaceutical, $\lambda$-Carrageenan, Diclofenac sodium, and all other chemicals were of analytical grade.

\section{Plant material}

Aerial parts of $L$. duriusculum (de Girard) Kuntze were collected in the flowering stage on May 2010 from the area of Mila in the North-East Algeria and authenticated by Professor Hocine Laouer (Ferhat Abbas University, Setif, Algeria) according to Quezel and Santa [5]. A voucher specimen (LDP0510-MIL-ALG-66) has been deposited in the Herbarium of the VARENBIOMOL research unit, University of Frère Mentouri Constantine1.

L. duriusculum was authenticated by Pr. A. Kaabeche (Biology Department, University of Setif, Algeria). A voucher specimen was deposited in the Herbarium of the Department of Natural and Life Sciences, Mentouri University, Constantine.

Leaves and flowers of $L$. duriusculum were dried and macerated with $\mathrm{EtOH}-\mathrm{H}_{2} \mathrm{O}(80: 20 \mathrm{v} / \mathrm{v})$ for $48 \mathrm{hr}$ three times. After removing the chlorophyll, the remaining aqueous solution was extracted successively with $\mathrm{CHCl}_{3}, \mathrm{EtOAc}$, and $n-\mathrm{BuOH}$ resulting in chloroform ethylacetate and $n-\mathrm{BuOH}$ extracts. The $n$-BuOH extract of $L$. duriusculum was chromatographed on a 230-400 mesh silica gel column eluted with a gradient of hexane-EtOAc-MeOH to yield fractions from which compounds were isolated and purified by preparative TLC on silica gel using $\mathrm{CH}_{2} \mathrm{Cl}_{2}$-acetone, hexane-EtOAc, and $\mathrm{CH}_{2} \mathrm{Cl}_{2}-\mathrm{MeOH}$ as elution systems. The $n$ - $\mathrm{BuOH}$ extract of $L$. duriusculum (BEL) and their major constituents apigenin (APG1) and apigenin7-O- $\beta$-(6"methylglucuronide) (APG2) were investigated in the present study. 


\section{Cell line and cultures}

The human colon adenocarcinoma-derivedHCT116 p53+/+ cell line was obtained from B. Vogelstein (The Johns Hopkins Kimmel Cancer Center, Baltimore, Maryland, USA). Cells were maintained in RPMI supplemented with 10\% fetal bovine serum (FBS), $2 \mathrm{mM} \mathrm{L}$-Glutamine and $1 \mathrm{X}$ penicillin/streptomycin mixture (Pen/Strep) in humidified atmosphere at $37{ }^{\circ} \mathrm{C}$ and $5 \% \mathrm{CO} 2$. The THP-1 human monocyte cell line was maintained in RPMI 1640 medium supplemented with 10\% inactive fetal bovine serum, $1 \%$ L-glutamine, $1 \%$ of penicillin/Streptomycin mixture in humidified atmosphere at $37^{\circ} \mathrm{C}$ and $5 \% \mathrm{CO}_{2}$.

\section{Drugs and reagents}

\section{Immunomodulatory study: Luciferase assay}

$1.8 \times 10^{5} /$ well/500 $\mu \mathrm{L} \mathrm{HCT} 116 \mathrm{p} 53^{+/+}$cells were seeded in 24 -well plates, transfected after $24 \mathrm{hr}$ with 350 ng of pGL3-basic-NF-KB-RE, containing a consensus NF-KB binding site, or pGL3-basic-empty plasmids and co-transfected with $50 \mathrm{ng}$ of pRL-SV40 plasmid as internal control to evaluate transfection efficiency using Mirus TransIT-LT1 reagent. After $24 \mathrm{hr}$, the cells were incubated with $\mathrm{IC}_{50}$ concentration -determined in a previous work by [10]- or $1 / 2 I_{50}$ of the compounds given alone or in combination with $10 \mathrm{ng} / \mathrm{mL}$ TNF- $\alpha$ for an additional $16 \mathrm{hr}$. Luciferase activities from cell lysates were then measured using the Dual-Luciferase Reporter Assay System and a Tecan Infinite 200 PRO Microplate Reader. The reporter activity was expressed as relative light units (RLs) of pGL3-basic-NF-kB-RE/ pRL-SV40 ratios and expressed as fold of induction over the control treatment.

\section{In vitro anti-inflammatory studies: cell viability assay in THP-1 cells}

$5 \times 10^{5}$ THP-1 cells $/ \mathrm{mL}$ were seeded in 96 -well plate $(95 \mu \mathrm{l}$ aliquots into each well) and incubated with $\mathrm{BEL}$ at concentrations ranging from 6.25 to $100 \mu \mathrm{g} / \mathrm{mL}$ or apigenin (APG1) from 5 to $80 \mu \mathrm{M}$. DMSO at $0.1 \%$ or $0.08 \%$ was used as a negative control for BEL and APG1, respectively. After 5 or $24 \mathrm{hr}$ of incubation, 10 $\mu \mathrm{l} \mathrm{OZ} \mathrm{Blue} \mathrm{reagent} \mathrm{was} \mathrm{added} \mathrm{to} \mathrm{the} \mathrm{THP-1} \mathrm{cells} \mathrm{and} \mathrm{incubated} \mathrm{for} 3 \mathrm{hr}$. The fluorescence intensity of viable cells at 590nm emission was measured using Tecan Infinite 200 PRO Microplate Reader.

\section{In vitro anti-inflammatory studies: LPS treatment of THP-1 cells and quantitative real-time polymerase chain reaction ( $q R T-P C R)$}

$2 \times 10^{6} \mathrm{THP}-1$ cells/well/2mL were seeded in 6 -well plates and treated with IC50, $1 / 2$ IC50 and $1 / 4$ IC50 of each compound given alone or in combination with Lipopolysaccharide (LPS), which was used to activate the canonical NF-KB pathway [11]. Cells were incubated for $5 \mathrm{hr}$ before measuring the pro-inflammatory cytokines IL- 6 and TNF- $\alpha$ by quantitative real-time polymerase chain reaction (qRT-PCR). Total RNA was extracted from THP-1 cells using RNAspin Mini RNA Isolation Kit (GE Healthcare). cDNA was synthesized from $1 \mu \mathrm{g}$ of RNA using RevertAid First Strand cDNA Synthesis Kit (ThermoFisher, Milan, Italy). qPCR was performed on a Bio-Rad CFX384 (Bio-Rad, Milan, Italy), starting with an equivalent of 25ng of cDNA. Relative mRNA quantification was obtained using the $\mathrm{Cq}$ method; the Glyceraldehyde 3-phosphate dehydrogenase (GAPDH) and the b2Microglobulin (B2M) genes were used as reference genes.

\section{In vivo Anti-inflammatory studies}

\section{Animals}

One-hundred male Wistar albino rats weighing $220 \pm 10 \mathrm{~g}$, obtained from the Pasteur Institute (Algiers, Algeria) were used. The animals were housed in polypropylene cages that were sanitized every $48 \mathrm{~h}$. The rats were maintained on a 12:12-h light:dark cycle, at a temperature of $23 \pm 1{ }^{\circ} \mathrm{C}$ and a relative humidity of $40 \pm 5 \%$ and allowed to acclimatize in this condition for two weeks prior to experimental use. The animals received ad libitum standard laboratory diet (standard food, supplied by the "ONAB of Bejaia", Algeria) and clean tap water. All protocols in this study were used in accordance with the guidelines of the Committee on Use of Laboratory Animals and approved under the PRFU project (D01N01UN250120190002) by the Ethical Committee of DGRSDT at the Algerian Ministry of Higher Education and Scientific Research. 
Acute toxicity evaluation of BEL

To determine the extract acute toxicity of the BEL fraction, five rats were treated with a single oral dose of $2000 \mathrm{mg} / \mathrm{kg}$ of BEL. The animals were kept overnight fasting before gavage with BEL. They were observed individually at least once during the first 30 min after administration, then periodically during $24 \mathrm{hr}$ (with special attention for the first $4 \mathrm{hr}$ ) and daily thereafter for a period of 14 days. General behavioral changes, common side effects such as mild diarrhea, weight loss were needed to be investigated [12].

\section{Carrageenan-induced paw edema}

For animal treatment, BEL and both APG1/APG2 were dissolved in DMSO (final concentration 0.1\%) according to an earlier report [13]. BEL was administrated orally whereas, apigenins were administered intraperitoneally (i.p) [14]. The animals were divided in six groups each of which contained five rats:

- Group I, normal control group: was treated (0.1\% v/v DMSO i.p; PBS p.o)

- Group II, standard Diclofenac sodium group: was treated with Diclofenac sodium (10 mg/kg b.w., p.o) [15].

- Group III, IV, BEL-groups: were treated orally with BEL (100 and $200 \mathrm{mg} / \mathrm{kg}$ ) respectively.

- Group V and V I, apigenin-groups: were treated with APG1, orAPG2 compounds, respectively, at a dose of $20 \mathrm{mg} / \mathrm{kg}$ b. w., i.p. [16].

Sixty minutes later, paw edema was induced by injecting $0.1 \mathrm{~mL}$ of $1 \%$ carrageenan into sub plantar tissue of the left hind paw of the rats. The progression of edema ( $\mathrm{mL}$ at $1,2,3,4$, and $5 \mathrm{hr}$ ) was evaluated measuring the paw by Plethysmograph. The percentage of edema inhibition as calculated for each group with respect to its vehicle-treated control group and edema was expressed as the increase in paw thickness $(\mathrm{mL})$ due to the inflammatory challenge. The percentage inhibition of the inflammation was calculated by:

$$
\% \text { inhibition }=\left(D_{0}-D_{t}\right) / D_{0} \times 100
$$

Where $D_{0}$ is the average inflammation (hind paw edema) of the control group of rats at a given time; $D_{t}$ is the average inflammation of the drug-treated rats (extract /compounds or Diclofenac-sodium reference) at the same time [17].

\section{Vascular permeability}

The in vivo vascular test of permeability was carried out according to a modified method of [18]. Six groups of five male rats each were fasted for $18 \mathrm{hr}$ before the experiment. Two BEL groups received 100 $\mathrm{mg} / \mathrm{kg}$ and $200 \mathrm{mg} / \mathrm{kg}$ of BEL orally, respectively. Two apigenin groups received $(20 \mathrm{mg} / \mathrm{mg} / \mathrm{kg}$., i.p.). A standard reference group received Diclofenac sodium (10 mg/kg b.w., p.o). The control group received $0.1 \%$ v/v DMSO; i.p; PBS, po.

Each animal was injected intravenously (iv) with $0.2 \%$ solution of Evans blue dye $1 \mathrm{hr}$ after the administration of the drugs. Fifteen minutes later, the rats were injected intraperitoneally, $1 \mathrm{~mL} / 100 \mathrm{~g}$ of body weight with freshly prepared $0.6 \%$ acetic acid in $\mathrm{NaCl} 0.9 \%$ solution. After 30 min, theywere sacrificed by cervical dislocation and the abdominal cavities were washed twice with $3 \mathrm{~mL}$ of PBS. The collected peritoneal fluids were then centrifuged at $4000 \mathrm{rpm}$ for $10 \mathrm{~min}$. The absorbance of the supernatant was measured at $600 \mathrm{~nm}$ in order to determine the concentration of the dye in the collected supernatants. A standard absorbance curve of Evans blue dye concentrations ranging from 1 to $50 \mu \mathrm{g} / \mathrm{mL}$ was determined.

\section{Carrageenan-induced Peritonitis}

For the determination of neutrophil migration into the peritoneal cavity, the control rats were injected i.p. with $2.0 \%$ DMSO. Both Diclofenac sodium $(10 \mathrm{mg} / \mathrm{kg})$ and BEL $(100 \mathrm{mg} / \mathrm{kg} / 200 \mathrm{mg} / \mathrm{kg})$ were administered orally 1 hour prior to the induction of peritonitis, whereas both APG1 and APG2 (20 mg/kg) were injected by i.p. route. After 1 hour, $1 \%$ solution of carrageenan (dissolved in PBS; pH 7.4) was injected i.p. Four hours later, the animals were sacrificed by cervical dislocation and $2 \mathrm{~mL}$ of heparinized PBS was injected into the peritoneal cavity. Following a gentle massage, peritoneal exudates were removed. Exudates cells were counted with the automatic cell counter, following staining Turk's solution $(0.2 \%$ crystal violet dye in $30 \%$ acetic acid) [19]. Results were expressed as the number of cells per milliliter of peritoneal wash exudates. Aliquots of the peritoneal exudates were stored at $-80{ }^{\circ} \mathrm{C}$ for subsequent analysis of myeloperoxidase activity. 
Myeloperoxidase (MPO) activity assay

MPO assay was based on the method of [20] and partly modified. Briefly, $400 \mu \mathrm{L}$ of the peritoneal exudates was centrifuged at $40,000 \times g$ for $7 \mathrm{~min}$ at $4{ }^{\circ} \mathrm{C}$. After, $10 \mu \mathrm{L}$ of the supernatants were collected and MPO activity was assayed measuring the change in absorbance at $450 \mathrm{~nm}$ by means of $O$-dianisidine dihydrochloride and $1 \%$ hydrogen peroxide. The results were expressed in units $/ \mathrm{mL}$. A unit of MPO activity was defined as that converting $1 \mu \mathrm{mol}$ of hydrogen peroxide to water in $1 \mathrm{~min}$ at $22{ }^{\circ} \mathrm{C}$.

\section{Statistical analysis}

Data were expressed as mean \pm S.D. For in vitro analysis, the post hoc test was done with Student's. ${ }^{*} \mathrm{p}<0.05$ was considered statistically significant. For in vivo analysis, data were analyzed using a one -way analysis of the variance test (One-way ANOVA) followed by Honest significant difference test (HSD) of Tukey used as post hoc test to compare significance between groups at $p<0.05$ and $p<0.01$, using Openstat 2014 program.

\section{RESULTS}

\section{BEL and APG1 inhibit NF-KB-dependent transcriptional responses in HCT116 and THP-1 cells}

To determine whether BEL extract and apigenins can act as immunomodulators, their effect on NF-KB transcriptional activity in TNF- $\alpha$ - or LPS-stimulated cells was examined. HCT116 p53+/+ cells were transiently transfected with an NF-kB luciferase reporter plasmid, and its activity was found to be significantly reduced by both BEL extract and APG1 in a dose-dependent manner both in the absence or in the presence of exogenous TNF- $\alpha$ that was used as activator of NF-KB (Figure 1).
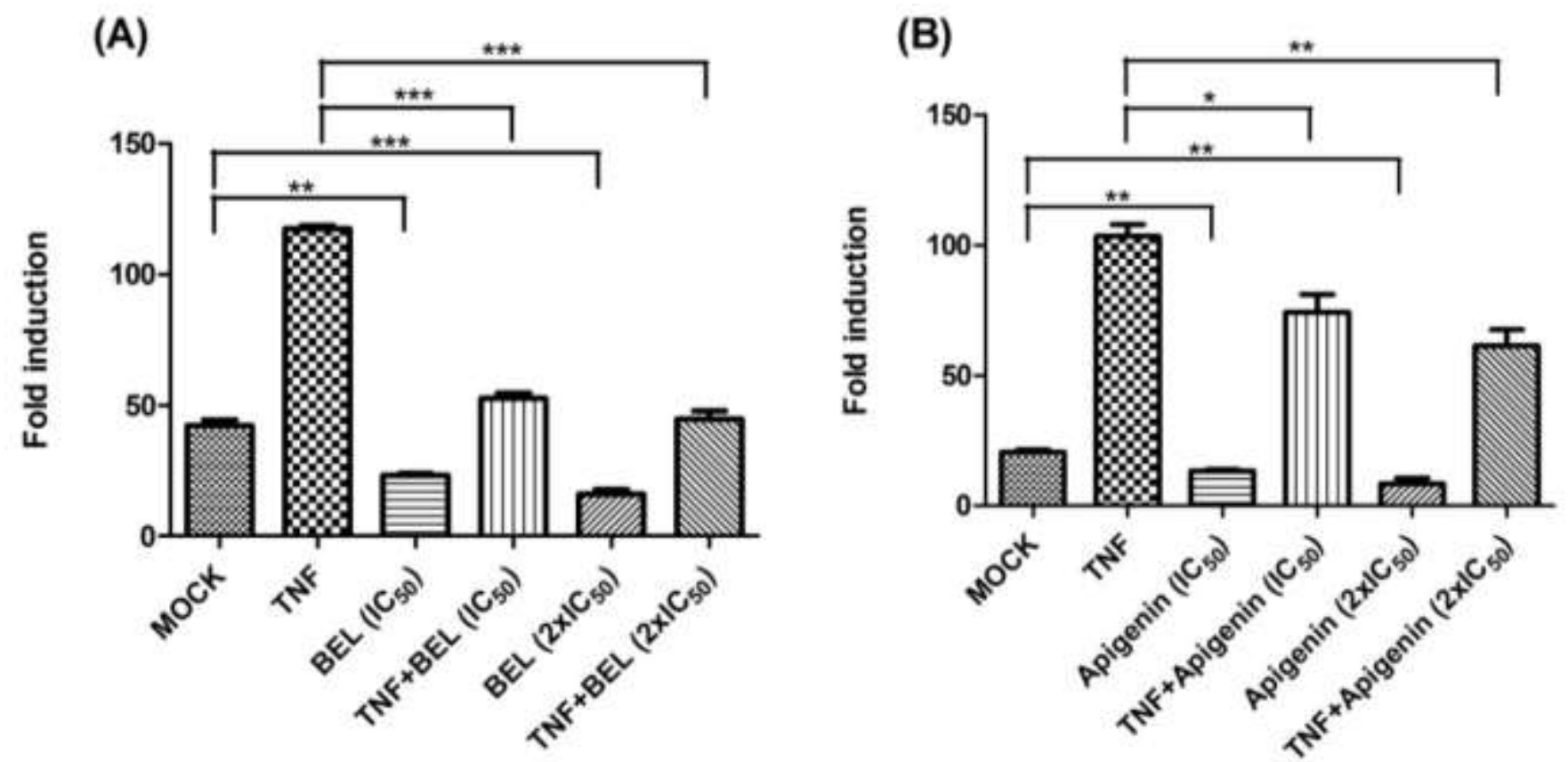

Figure 1. Inhibitory effects of BEL and apigenin on TNF- $\alpha$-induced activation of NF-KB.HCT116 p53+/+cells were transfected either with a NF-KB firefly luciferase reporter or an empty vector and with a control renilla luciferase plasmid and treated with IC50 or $1 / 2$ IC50 of BEL extract(A) or apigenin(B) alone or in combination with TNF-a (10ng/ml) for 16 hours. For each condition, graphs plot the average fold of induction over the empty vector and the standard deviation of three biological replicates. ${ }^{*} p<0.05,{ }^{* *} p<0.01,{ }^{* * *} p<0.001$. 
The experiment was extended to the monocyte-derived THP-1 cell line where the activation of endogenous IL-6 and TNF- $\alpha$ genes after treatment with LPS depends on the activation of NF-KB [21]. Firstly, the $I_{50}$ of BEL and APG1 in THP-1 cells was determined. Cell viability was not affected at the lowest concentrations tested for BEL and APG1 $(5 \mu \mathrm{g} / \mathrm{mL}, 5 \mu \mathrm{M}$, respectively). However, at the highest concentrations used $(80 \mu \mathrm{g} / \mathrm{mL}, 80 \mu \mathrm{M}$, respectively), the cell viability was remarkably reduced down to $\sim 21$ and $47 \%$, respectively, at $24 \mathrm{hr}$ time point, with an $\mathrm{IC}_{50}$ of $95.34 \mu \mathrm{g} / \mathrm{mL}$ and $92.71 \mu \mathrm{M}$ for BEL and APG1, respectively (Figure $2 \mathrm{~A}, 2 \mathrm{~B})$. APG2 $(5 \mu \mathrm{M}$ to $80 \mu \mathrm{M})$ failed to show an inhibitory effect onTHP-1 cell (Figure $2 \mathrm{C}$ ).
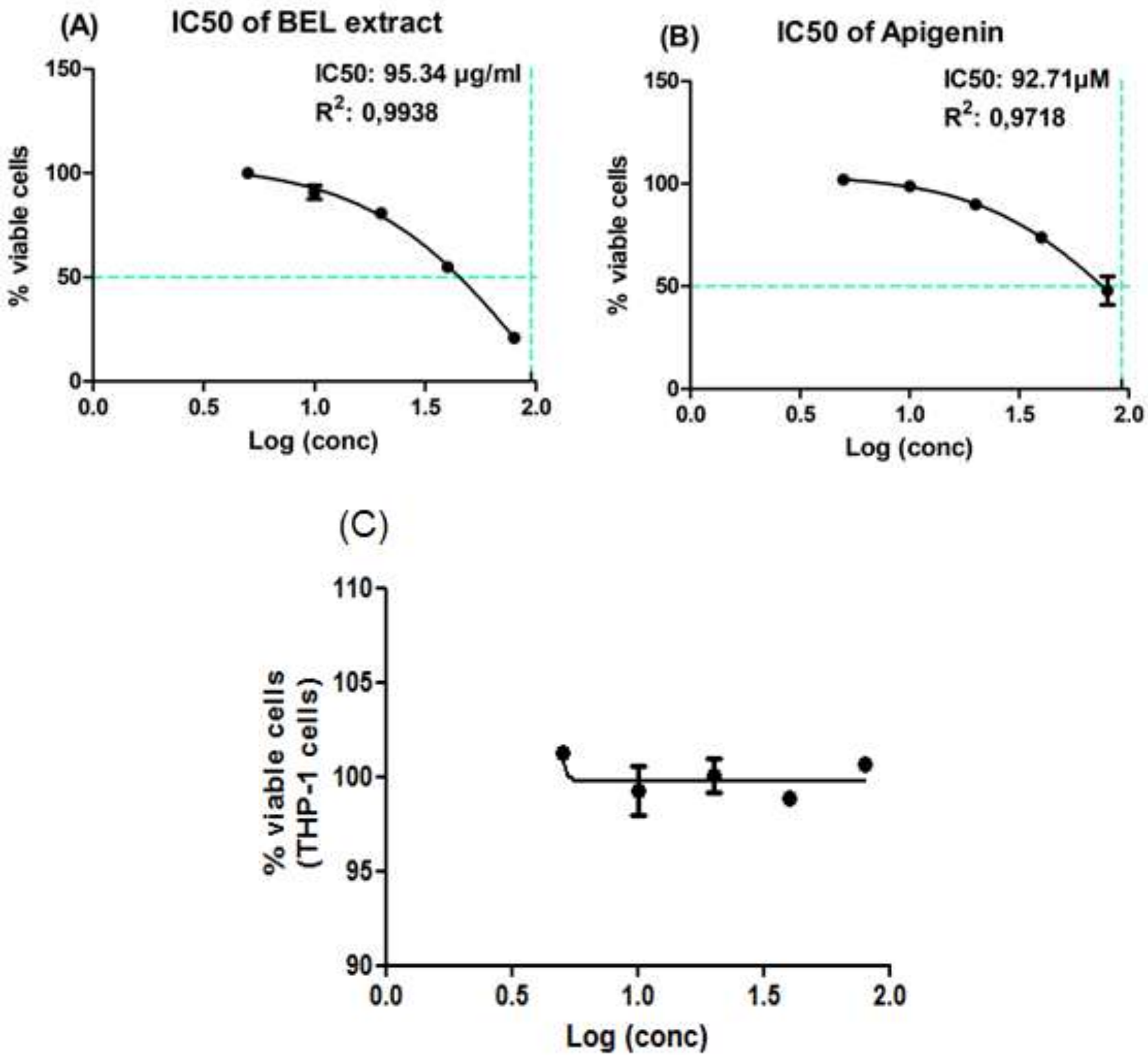

Figure 2. Anti-proliferative effect of BEL, APG1 and APG2 on THP-1 cells. THP-1 cells were incubated for 24 hourswith increasing concentrations of BEL $(6.25$ to $100 \mu \mathrm{g} / \mathrm{mL})(A)$, or APG1 (5 to $80 \mu \mathrm{M})(\mathrm{B})$, or APG2(5 to $80 \mu \mathrm{M})(\mathrm{C})$. Cell viability was determined by OZBlue staining and is expressed as percentage compared to the untreated cells. Results are plotted as mean \pm SD $(n=2)$. The IC50 of BEL was $95.34 \mu \mathrm{g} / \mathrm{mL}$; the IC50 of Apigenin was $92.71 \mu \mathrm{M}$. 
THP- 1 cells were then treated with the compounds for $5 \mathrm{hr}$ at $1 \times 1 \mathrm{IC} 50,1 / 2 \times \mathrm{IC} 50,1 / 4 \times \mathrm{IC} 50$ for BEL and APG1, alone or in combination with LPS $(10 \mu \mathrm{g} / \mathrm{mL})$. The expression of IL-6 and TNF- $\alpha$ mRNAs was determined by qRT-PCR. BEL extract and APG1 alone modulated only slightly, if at all, the low-level, basal expression of IL-6. LPS treatment led to high induction of IL-6 expression, as expected. Both BEL and APG1 inhibited dose-dependently and almost completely the LPS-dependent induction of this interleukin gene. The results differed for the modulation of TNF- $\alpha$ mRNA expression. APG1 did not reduce the LPS-dependent induction of the mRNA except for a trend at the higher dose; it might in fact even have an additive effect with LPS at the lower doses. On the contrary, BEL showed a dose dependent effect: the $1 / 4$ IC50 concentration was inactive both on basal and induced levels of TNF- $\alpha$, while starting at $1 / 2$ IC 50 , there was a progressive reduction down to about $30 \%$ residual activation compared to LPS alone (Figure 3A, 3B). Collectively, the luciferase and qPCR results suggest an anti-inflammatory and NF-KB-inhibitory effect for both BEL extract and APG1.

(A)
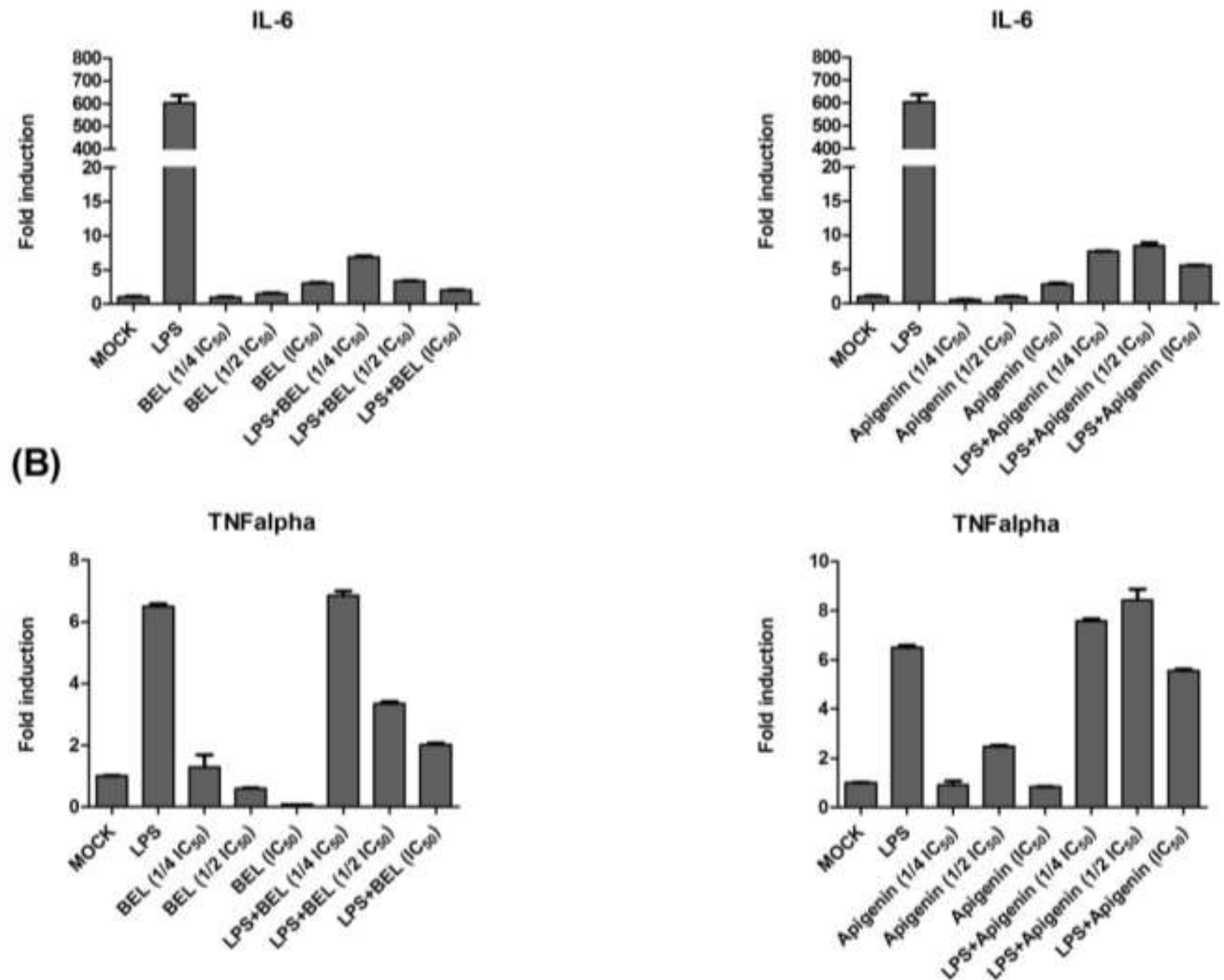

Figure 3. Impact of BEL or Apigenin treatment on the expression of pro-inflammatory cytokines. THP-1 cells were incubated withthreeconcentrations (1/4, 1/2, or IC50) of BEL (left panels) or Apigenin (right panels) alone or in combination with $10 \mu \mathrm{g} / \mathrm{mL}$ LPS, as an activator of NF-KB. Cells were collected after 5hrand total RNA was isolated for the measurement of IL-6 (A) and TNF- $\alpha(B)$ mRNA by quantitative real-time PCR. Gene expression was calculated relative to GAPDH and B2M reference genes. Mean \pm SD $(n=3)$ are plotted. 


\section{In vivo Anti-inflammatory studies}

\section{Acute toxicity evaluation of BEL}

Acute oral administration of BEL was found to be safe up to a dose of $2000 \mathrm{mg} / \mathrm{kg}$, p.o. During the following 14 days, administration of BEL produced no signs of acute toxicity in treated animals, no mortality and no abnormal behavior were noted. Two doses of $200 \mathrm{mg} / \mathrm{kg}$ and $100 \mathrm{mg} / \mathrm{kg}$ of BEL were selected for the evaluation of in vivo antinflammatory activities

\section{Carrageenan-induced paw edema in rats}

Carrageenan-induced edema has been commonly used as an experimental animal model of acute inflammation. The anti-inflammatory activity of the BEL $(100,200, \mathrm{mg} / \mathrm{kg})$ was dose-dependent. The intraplantar injection of carrageenan resulted in a noticeable increase in the mean volume of rats' paw which peaked at $3 \mathrm{hr}$ after stimuli $(1.23 \pm 0.01 \mathrm{~mL})$ (Table 1). BEL-treated group $(200 \mathrm{mg} / \mathrm{kg})$ showed a significant $(p<0.01)$ anti-edema effect (maximum effect of $67.13 \%$ reduction at the $4 \mathrm{hr}$ time point). The lower dose $(100$ $\mathrm{mg} / \mathrm{kg}$ ) was also effective but to a lower extent (43.59\%). Both isolated apigenins (APG1, APG2) exhibited a remarkable paw swelling inhibition; APG1 significantly $(p<0.05)$ inhibited carrageenan provoked rats paw swelling by $54.45 \%$ (3 hr time point), and was more effective compared to APG2 (42.02\%). The positive control Diclofenac inhibited (63.42\%) carrageenan-induced edema during the same period of time (Table 1).

Table 1. Effect of BEL, APG1 or APG2 on carrageenan induced- paw edema in rats

\begin{tabular}{|c|c|c|c|c|c|}
\hline \multirow{2}{*}{ Treatment } & \multicolumn{5}{|c|}{ Increase in paw edema $(\mathrm{mL})$ at different hours } \\
\hline & $1 \mathrm{~h}$ & $2 \mathrm{~h}$ & $3 \mathrm{~h}$ & $4 \mathrm{~h}$ & $5 \mathrm{~h}$ \\
\hline $\begin{array}{l}\text { Carrageenan } \\
\text { (Control) }\end{array}$ & $0.74 \pm 0.01$ & $0.85 \pm 0.03$ & $1.23 \pm 0.01$ & $1.00 \pm 0.06$ & $0.81 \pm 0.01$ \\
\hline $\begin{array}{l}\text { Diclofenac } \\
10 \mathrm{mg} / \mathrm{Kg}\end{array}$ & $\begin{array}{l}0.42 \pm 0.00^{* *} \\
(43.24 \%)\end{array}$ & $\begin{array}{l}0.44 \pm 0.01^{* *} \\
(48.70 \%)\end{array}$ & $\begin{array}{l}0.45 \pm 0.01^{* *} \\
(63.42 \%)\end{array}$ & $\begin{array}{l}0.38 \pm 0.01^{* *} \\
(62.15 \%)\end{array}$ & $\begin{array}{l}0.30 \pm 0.00^{* *} \\
(63.27 \%)\end{array}$ \\
\hline $\begin{array}{l}\text { BEL } \\
100 \mathrm{mg} / \mathrm{kg}\end{array}$ & $\begin{array}{l}0.60 \pm 0.00^{* *} \\
+\uparrow(18.49 \%)\end{array}$ & $\begin{array}{l}0.62 \pm 0.01^{* *} \\
\operatorname{t+}(27.38 \%)\end{array}$ & $\begin{array}{l}0.69 \pm 0.01^{* *} \\
\operatorname{t+}(43.33 \%)\end{array}$ & $\begin{array}{l}0.57 \pm 0.04^{* *} \\
\operatorname{t+}(43.59 \%)\end{array}$ & $\begin{array}{l}0.52 \pm 0.04^{* *} \\
\operatorname{t+}(35.97 \%)\end{array}$ \\
\hline $\begin{array}{l}\text { BEL } \\
200 \mathrm{mg} / \mathrm{kg}\end{array}$ & $\begin{array}{l}0.48 \pm 0.02^{* *} \\
++\S \S \\
(35.27 \%)\end{array}$ & $\begin{array}{l}0.48 \pm 0.00^{* *} \\
\operatorname{t+} \S(43.39 \%)\end{array}$ & $\begin{array}{l}0.48 \pm 0.01^{* *} \\
\S \S+\uparrow(60.56 \%)\end{array}$ & $\begin{array}{l}0.33 \pm 0.02^{\star *} \\
\operatorname{t+} \S(67.13 \%)\end{array}$ & $\begin{array}{l}0.29 \pm 0.03^{\star *} \\
\S \S(63.51 \%)\end{array}$ \\
\hline $\begin{array}{l}\text { APG1 } \\
(20 \mathrm{mg} / \mathrm{kg})\end{array}$ & $\begin{array}{l}0.54 \pm 0.01^{* *} \\
\operatorname{t+}(27.02 \%)\end{array}$ & $\begin{array}{l}0.56 \pm 0.02^{* *} \\
\operatorname{t+}(34.68 \%)\end{array}$ & $\begin{array}{l}0.56 \pm 0.00^{* *} \\
\uparrow \uparrow ¥ ¥(54.45 \%)\end{array}$ & $\begin{array}{l}0.51 \pm 0.01^{* *} \\
\uparrow \uparrow(49.68 \%)\end{array}$ & $\begin{array}{l}0.44 \pm 0.04^{* *} \\
\uparrow \uparrow(45.915 \%)\end{array}$ \\
\hline $\begin{array}{l}\text { APG2 } \\
(20 \mathrm{mg} / \mathrm{kg})\end{array}$ & $\begin{array}{l}0.56 \pm 0.00^{* *} \\
\text { †† } ¥ ¥(24.72 \%)\end{array}$ & $\begin{array}{l}0.58 \pm 0.02^{* *} \\
\text { 十巾 } ¥(31.76 \%)\end{array}$ & $\begin{array}{l}0.71 \pm 0.01^{* *} \\
+\uparrow(42.02 \%)\end{array}$ & $\begin{array}{l}0.51 \pm 0.01^{* *} \\
+t(49.20 \%)\end{array}$ & $\begin{array}{l}0.46 \pm 0.01^{\star *} \\
\text { t†¥¥ (42.97\%) }\end{array}$ \\
\hline
\end{tabular}

Each value is the mean $\pm S D(n=5)$;

* : comparison vs control $\left({ }^{*}: p<0.05 ;{ }^{* *}: p<0.01\right)$,

$\uparrow$ : comparison vs Diclofenac $(\uparrow: p<0.05 ; \uparrow \uparrow: p<0.01)$,

$\S$ : comparison BEL100mg/kg vs BEL200 mg/kg(§: $p<0.05 ; \S \S: p<0.01)$,

$¥$ : comparison APG1vs APG2 ( $: p<0.05$; $¥: p<0.01$ ),

Values given in parentheses are the percentages of inhibition

\section{Vascular permeability}

The vascular permeability test is one of the acute inflammatory models. As shown in Table 2 , the dye leakage induced by acetic acid was significantly $(p<0.01)$ inhibited by BEL. The inhibition of the vascular permeability by BEL was dose-dependent, the lower dose of $100 \mathrm{mg} / \mathrm{kg}$ being less efficient $(39.20 \%)$ than the higher one of $200 \mathrm{mg} / \mathrm{kg}(66.95 \%)$. The early vascular permeability was also significantly inhibited in the groups receiving intraperitoneal injection of $20 \mathrm{mg} / \mathrm{kg}$ apigenins, compared to the control group. The reduction in vascular permeability due to APG1 was significantly greater $(54.44 \%)$ than that caused by APG2 (41.87\%), but lower compared to effect of Diclofenac $(72.12 \%)$. 
Table 2. Effect of BEL, APG1 or APG2 on vascular permeability.

\begin{tabular}{ll}
\hline Treatment & Vascular Permeability -Absorbance \\
\hline Carrageenan(Control) & $2.72 \pm 0.34$ \\
Diclofenac10 $\mathrm{mg} / \mathrm{Kg}$ & $0.27 \pm 0.03^{* *}(\mathbf{7 2 . 1 2} \%)$ \\
BEL100 $\mathrm{mg} / \mathrm{kg}$ & $0.58 \pm 0.03^{* *}+\uparrow(39.20 \%)$ \\
BEL200 $\mathrm{mg} / \mathrm{kg}$ & $0.32 \pm 0.01^{* *} \uparrow \uparrow \S \S(66.95 \%)$ \\
APG1 $(20 \mathrm{mg} / \mathrm{kg})$ & $0.44 \pm 0.02^{* *}+\uparrow(54.44 \%)$ \\
APG2 $(20 \mathrm{mg} / \mathrm{kg})$ & $0.56 \pm 0.03^{* *}+\uparrow ¥ ¥(\mathbf{4 1 . 8 7} \%)$ \\
\hline
\end{tabular}

Each value is the mean $\pm S D(n=5)$;

${ }^{*}$ : comparison vs control $\left({ }^{*}: p<0.05 ;{ }^{* *}: p<0.01\right)$,

$\uparrow:$ comparison vs Diclofenac ( $\uparrow: p<0.05 ; \uparrow$ : $p<0.01)$,

$\S$ : comparison BEL100mg/kg vs BEL200 mg/kg (§: $p<0.05 ; \S \S: p<0.01)$,

$¥$ : comparison APG1vs APG2 ( $¥: p<0.05 ; ¥ ¥: p<0.01)$,

Values given in parentheses are the percentages of inhibition

\section{Carrageenan-induced peritonitis}

Total Leukocyte and neutrophil migration into the peritoneal cavity in rats

To further evaluate its anti-inflammatory effects, BEL was tested in a carrageenan-induced model of peritonitis. The basal concentration of both total leucocytes and neutrophils cells in the peritoneal cavity was $2.72 \pm 0.34$ and $0.32 \pm 0.10 \times 10^{6}$ cells $/ \mathrm{mL}$, respectively. However, $4 \mathrm{hr}$ after carrageenan administration, this concentration increased to $14.92 \pm 0.75$ and $10.64 \pm 1.06 \times 10^{6}$ cells $/ \mathrm{mL}$, respectively (Table 3 ).

Table 3. Effect of BEL APG1 or APG2 on carrageenan-induced peritonitis

\begin{tabular}{lll}
\hline Treatment & Total Leucocytes & Neutrophils \\
\hline Vehicle & $2.72 \pm 0.34^{* *}(81.77 \%)$ & $0.32 \pm 0.10^{* *}(97.01 \%)$ \\
Carrageenan(Control) & $14.92 \pm 0.75$ & $10.64 \pm 1.06$ \\
Diclofenac $100 \mathrm{mg} / \mathrm{Kg}$ & $4.15 \pm 0.53^{* *}(\mathbf{7 2 . 1 8} \%)$ & $2.69 \pm 0.36^{* *}(\mathbf{7 4 . 6 9} \%)$ \\
BEL $100 \mathrm{mg} / \mathrm{kg}$ & $7.69 \pm 0.65^{* *}+\uparrow(\mathbf{4 8 . 4 6} \%)$ & $6.34 \pm 0.18^{* *}+\uparrow(\mathbf{4 0 . 4 6} \%)$ \\
BEL $200 \mathrm{mg} / \mathrm{kg}$ & $5.36 \pm 0.28^{* *}+\uparrow \S \S(64.09 \%)$ & $3.25 \pm 0.32^{* *}+\uparrow \S \S(69.50 \%)$ \\
APG $1(20 \mathrm{mg} / \mathrm{kg})$ & $6.32 \pm 0.61^{* *}+\uparrow(\mathbf{5 7 . 6 4} \%)$ & $5.60 \pm 0.36^{* *}+\uparrow(\mathbf{4 7 . 3 6} \%)$ \\
APG $2(20 \mathrm{mg} / \mathrm{kg})$ & $7.95 \pm 0.52^{* *}+\uparrow ¥ ¥(\mathbf{4 6 . 7 3} \%)$ & $6.67 \pm 0.32^{* *}+\uparrow ¥ ¥(\mathbf{3 7 . 3 2} \%)$ \\
\hline
\end{tabular}

Each value is the mean $\pm S D(n=5)$;

${ }^{*}$ : comparison vs control $\left({ }^{*}: p<0.05 ;{ }^{* *}: p<0.01\right)$,

$\uparrow:$ comparison vs Diclofenac $(\uparrow: p<0.05 ; \uparrow t: p<0.01)$

$\S$ : comparison BEL100mg/kg vs BEL200 mg/kg (§: $p<0.05 ; \S \S: p<0.01)$,

$¥:$ comparison APG1vs APG2 ( $: p<0.05 ; ¥ ¥: p<0.01)$,

Values given in parentheses are the percentages of inhibition 
The higher dose of BEL $(200 \mathrm{mg} / \mathrm{kg})$ resulted in a significant $(p<0.01)$ decrease in both leukocyte and neutrophils influx to peritoneal cavities, (64.09\%, $69.50 \%$, respectively) (Table 3). The lower dose (100 $\mathrm{mg} / \mathrm{kg}$ ), was also effective, but to a lower extent (48.46\%, 40.46\%). Both APG1 and APG2 treatments led to reduction in leukocyte and neutrophil influx, but APG1 was more potent $(57.64 \%, 47.36 \%$, respectively) than APG2 (46.73\%, $37.32 \%)$. In this assay, the inhibition produced by Diclofenac was found to be $72.18 \%$ and $74.69 \%$, respectively (Table 3 ).

MPO activity

Carrageenan-induced peritonitis also resulted in a significant $(p<0.01)$ increase $(8.94 \pm 0.55 \mathrm{U} / \mathrm{mL})$ in the MPO activity in the tissue of the peritoneal exudates. BEL treatment led to a dose-dependent decrease in MPO activity (64.05\% and $36.48 \%$ respectively for $200 \mathrm{mg} / \mathrm{kg}$ and $100 \mathrm{mg} / \mathrm{kg})$. APG1 (58.37\%) was more efficient than APG2 (41.92\%). The Diclofenac-sodium was the most effective for this endpoint $(66.18 \%$ decrease) (Table 4).

Table 4. Effect of BEL APG1 or APG2 on MPO level in peritoneal exudates.

Treatment Relative enzymatic activity (units $/ \mathrm{mL}$ )

Carrageenan (Control)

Diclofenac $100 \mathrm{mg} / \mathrm{Kg}$

BELD $100 \mathrm{mg} / \mathrm{kg}$

BELD $200 \mathrm{mg} / \mathrm{kg}$

APG $1(20 \mathrm{mg} / \mathrm{kg})$

APG $2(20 \mathrm{mg} / \mathrm{kg})$
$8.94 \pm 0.55$

$3.02 \pm 0.24^{* *}(66.18 \%)$

$5.68 \pm 0.37^{* *}+\uparrow(36.48 \%)$

$3.21 \pm 0.13^{* *}+\uparrow \S \S(64.05 \%)$

$3.72 \pm 0.37^{* *}+(58.37 \%)$

$5.19 \pm 0.08^{* \star} \uparrow \uparrow ¥ ¥(41.92 \%)$

\footnotetext{
Each value is the mean $\pm S D(n=5)$;

${ }^{*}$ : comparison vs control $\left({ }^{*}: p<0.05 ;{ }^{* *}: p<0.01\right)$,

$\uparrow:$ comparison vs Diclofenac ( $\uparrow: p<0.05 ; \uparrow \uparrow: p<0.01)$,

$\S$ : comparison BEL100mg/kg vs BEL200 mg/kg $(\S: p<0.05 ; \S \S: p<0.01)$,

$¥:$ comparison APG1vs APG2 ( $: p<0.05$; $¥: p<0.01)$,

Values given in parentheses are the percentages of inhibition
}

\section{DISCUSSION}

It is well established that excessive inflammation plays a key role in many human diseases, including cancer $[22,23]$. Dysregulated inflammation leads to increased NF-KB activity and induces the expression and secretion of inflammatory mediators and apoptosis [24]. Numerous studies have shown that NF-kB is a key regulator of inflammatory and immune responses by controlling the expression of a large number of proinflammatory genes, such as TNF- $\alpha, \mathrm{IL}-6, \mathrm{IL}-1 \beta, \mathrm{IL}-8$ [25], and plays a critical role in cancer progression [2628].

Given the reported anti-inflammatory properties of APG1 [29], and the use of Limonium duriusculum in traditional medicine as an anti-inflammatory treatment, the present study evaluated the specific impact of $n$ $\mathrm{BuOH}$ extract of $L$. duriusculum (BEL) extract, APG1, and APG2 on NF-KB transcriptional activity. The results obtained in HCT116 cells confirmed that BEL was more effective than APG1 in inhibiting NF-KB activity in reporter gene assays.BEL extract was also more effective than APG1 in reducing LPS-dependent mRNA expression of both the pro-inflammatory cytokines IL- 6 and TNF- $\alpha$ in dose dependent manner in THP-1 cells. APG1 had an impact on TNF- $\alpha$ mRNA levels only at the highest dose used. Therefore, it is likely that BEL and APG1-mediated suppression of LPS-induced proinflammatory cytokines in THP-1 cells is dependent on the downregulation of the NF-KB pathway. In human cell cultures, apigenin has exhibited the ability to 
inactivate NF-KB, mediated by suppression of LPS-induced nuclear translocation of the p65 subunit[30], and also by reducing its phosphorylation [31]. It has been reported that apigenin inhibits inflammatory responses via inhibition of LPS-induced expression of iNOS, COX-2, pro-inflammatory cytokines (IL-1 $\beta$, IL-2, IL-6, IL-8, and TNF- $\alpha$ ), AP-1 proteins (c-Jun, c-Fos, and JunB), and the production of nitric oxide [32]. The BEL effect might be explained by the combination of the apigenins compounds contained in BEL with other constituents that possibly work through complementary pathways. In this respect, the current shift from the "one-diseaseone-drug" to a "combinational strategy" paradigm in drug discovery, opens up opportunities for traditional plant medicine[29].

Aiming at further exploring the anti-inflammatory properties of BEL, the current in vivo study focused on paw swelling and leukocyte aggregation at the injury site, as fundamental events in the inflammatory process resulting from carrageenan treatment [33].Oral treatment with the BEL produced significant inhibition of carrageenan-induced paw edema that was dose-dependent from the first to the fifth hour and time-dependent until the first three hours. Moreover, both isolated apigenins had a rapid effect on edema already at the first hour after carrageenan challenge. Numerous inflammatory mediators might act in cascade to generate inflammation [34], and the initial phase of the edema (with a peak effect at $3 \mathrm{hr}$ in our treatment) is thought to be due to the release kinine-like peptides, mainly bradykinin. However, the second phase is owing to prostaglandins and protease release [35].Since BEL and both its major components (APG1/APG2) were able to prevent both phases of inflammation by different degrees, these results suggested that the antiedematogenic effect of BEL might be related to the inhibition of one or more intracellular signaling pathways involved in the release of the TNF- $\alpha$ mediators, mentioned above.

Vascular permeability changes and vasodilation participate in pathophysiology of inflammation with leakage of vascular contents to interstitial tissue [19].To highlight the anti-inflammatory impact of the BEL and their apigenins isolated compounds, their actions on the amplification phase of inflammation, assaying vascular permeabilitywere assessed. Cell migration and leucocytes recruitment within the sites of injury and infection is an important multistep process of inflammation [36]. To evaluate the participation of leukocyte migration in the anti-inflammatory activity mediated by BEL and their apigenins compounds, the carrageenaninduced peritonitis model assay was performed. BEL and its isolated apigenins administration also resulted in a significant decrease in both leukocyte and PN influx to peritoneal cavities. This effect was also more pronounced in the case of BEL treatment.

These results suggest that apigenin might act through multiple mechanisms to modulate inflammatory responses. Although, it is well thought that apigenin is safe even at high doses [37], its efficiency depends largely on the route of administration. Numerous studies reported that the in vivo dose of apigenin have been typically in the range of body $20-50 \mathrm{mg} / \mathrm{kg}$. El Shoubaky and coauthors [38] reported that the oral pretreatment with apigenin (50 mg/kg) prevents the rat carrageenan induced acute paw edema. Zhao and coauthors [39] declared that oral intake of apigenin $(40 \mathrm{mg} / \mathrm{kg})$ in mice for 3 months displayed neurovascular protective effect, whileZheng and coauthors [40] mentioned that $30 \mathrm{mg} / \mathrm{kg}$ of Apigenin-7-glucoside showed hepatoprotective effect. Zhang and coauthors and Liu coauthors [16,41] indicated that $20 \mathrm{mg} / \mathrm{kg}$ of apigenin exhibited neuroprotective effects in pretreated mice. Similarly, apigenin treatment $(20 \mathrm{mg} / \mathrm{kg})$ of rats was able to reverse renal damage induced by cyclosporine [42]. Shukla and coauthors [43] mentioned that the oral administration of apigenin ( $50 \mu \mathrm{g} / \mathrm{mice})$, decreased the volume and wet weight of tumors in nude mice bearing human prostate cancer cells, without any undesirable side effects.

Consistent with the previous findings, it was also found that APG1/ APG2 (20 mg/kg, i.p.) significantly, inhibited the carrageenan-induced paw swelling, vascular permeability and leukocyte influx in mice to different degrees. Gradolatto and coauthors [14] reported that absorption and elimination phase of apigenin via oral route is very slow, and that apigenin has general tendency to accumulate in tissue after oral administration as a large amount of yellow granules.

Since Limonium is an apigenin-rich plant, it is not surprising that besides its antitumor effect [10], antiinflammatory effects were proven. The fact that BEL was more pronounced at $200 \mathrm{mg} / \mathrm{kg}$, oral administration is in agreement with previous reports showing that $200 \mathrm{mg} / \mathrm{kg}$ was the effective hepatoprotective dose for both Limonium tetragonum[44] and Limonium sinense[45].

These results corroborate also with study from the ethanolic extract of Chamomile (Matricaria chamomilla), which is extremely rich in apigenin, that at $200 \mathrm{mg} / \mathrm{kg}$ or $500 \mathrm{mg} / \mathrm{kg}$ for 15 days, showed a significant memory-enhancing activity [46]. The flavonoids potentially display a multitargeting antiinflammatory action [47]. Several mechanisms are proposed to explain anti-inflammatory action of flavonoids such as the inhibition of eicosanoid generating enzymes including phospholipase A2, cyclooxygenases, lipoxygenases [44]. The inhibition of neutrophil degranulation and the affecting a number of key signaling 
pathways [48]. The present results suggest that BEL suppresses the phases of carrageenan-induced paw edema, thus, confirming an NSAID-like property. Inhibition of prostaglandin synthesis by direct interference with the cyclooxygenase enzymes is a common mechanism of non-steroidal anti-inflammatory drugs (NSAIDs) [49]. The effectiveness of LBE and APG1apigenin at all over hours possibly indicated their antagonistic effect on prostaglandin, bradykinin, histamine, and serotonin. It seems that LBE might be containing some anti-inflammatory agent which is responsible for the blockage of prostaglandins and inflammatory pathway. A number of phytochemical reports in the literature have shown that the potencies of anti-inflammatory activity depend on the patterns and numbers of hydroxylation(s) on the A/B-ring. The 5,7hydroxylation on the A ring and 4'-hydroxylation on the B-ring are favorable [48]. It has been reported that flavones such as apigenin and luteolin, strongly down-regulate proinflammatory gene expression, and were shown to be potent inhibitors of the expression of the cytokine-induced adhesion molecules by endothelial cells [50]. Petkov and coauthors [51] revealed that the inhibition of the release of histamine process occurs with a number of hydroxylated flavones, aglycones, whereas much lower inhibition occurs with methoxylated flavones.

The anti-inflammatory responses of BEL and their major apigenin compounds that might enhance their effectiveness, can be attributed to the structure-property activity and the type of functional groups. The two apigenin major components differ in the chemical structure: in apigenin7-0- $\beta$-(6"-methylglucuronide), the 7hydroxy group of apigenin is replaced by a-methylglucuronide group. This structural difference between APG1 and APG2 might contribute to the differences in the response effect.

The substitutions on the apigenin ring structure have been shown to correlate with an COX inhibitory activity [37]. Previous studies indicated that 4' position on the apigenin B-ring induced the cell-cycle arrest [52].The presence of the C2-C3 double bond with 4-oxo functional group of the C-ring is essential to the growth-inhibitory potential [53] and the anti-inflammatory effect [52]. It was suggested that the extent and topology of hydrogen bonds possibly formed by the polyhydroxy flavone is crucial for the interaction target site [54].

Despite the prominent effect of the major compounds APG1/APG2 present in BEL, the contribution of other two new flavones (duriusculin A, duriusculin B) could receive increasing attention. The finding obtained from the current studydeclares, for the first time that cellular markers of anti-inflammatory responses are more pronounced in response to BEL extract than to equivalent doses of isolated apigenins.

In the present study, the effectiveness of apigenin-rich BEL might be effectively explained by the presence of high amounts of apigenin and apigenin7-O- $\beta-(6$ "-methylglucuronide), and also by the pinoresinollignan as mentioned by our previous phytochemical study [9] that have shown promising beneficial effects for human health and has been declared as an anti-inflammatory, antioxidant, cytotoxic agent [55], whose effect could be related to the "furofuran" structure. This different behavior between the isolated compounds (apigenins) and the plant extract (BEL) represents one of the most critical points of the investigation related to their biological action in both anti-proliferative and inflammation. Consistent with previous findings, it was found that APG1 alone significantly inhibited cell proliferation, exhibited in vitro and in vivo anti-inflammatory effect, while APG2 only showed a weak in vivo anti-inflammatory effect and was inactive in vitro. The BEL fraction exhibited in vitro and in vivo anti-inflammatory properties more effective than both their isolated apigenins. Nevertheless, some considerations must be drawn regarding its substitute form depending on the administration route. These findings were supported by literature data indicating that glycosylated compounds have generally less efficacy in different model systems in vitro, suggesting that effects on metabolism offer partial explanation [56]. The glycosylated compounds might first be metabolized by extracellular enzymes before they can be absorbed by the intestinal tract. The moiety with which apigenin is conjugated is an important determinant of its absorption and bioavailability [14, 57]. Nicholas and coauthors [31] reported that apigenin aglycone can enter into cells of the innate immune system, in contrast to glycosylated forms which are excluded from the cell. Lin and coauthors [58] indicated that flavonoids with methoxyl groups, such as diosmetin or hesperetin were less rapidly degraded as compared to flavonoids without methoxyl groups. Therefore, these data reinforces the hypothesis of this study that the weak action of APG2 might be related to methylglucuronide group. In response to LPS, the present study further suggests that the decreased anti-inflammatory activity of APG2 can be in large part attributed to a lower transport/diffusion through the plasma membrane. Mechanisms for cellular influx of flavonoids are not well understood, and they might vary with the type of flavonoid and membrane transporters found in specific cell types. These data clearly indicate that flavone aglycone is more efficiently absorbed into serum than their corresponding glycosides, which is consistent with observations that flavonoids glycosides must first be deconjugated to aglycones prior to intestinal absorption [59]. 
The BEL fraction might have a complex and synergistic behavior when evaluated on inflammation function due to the presence of different polyphenolic compounds, most of them in conjugated form. Hence, Limonium duriusculum which is one of the plant richest in apigenin (APG1, $1.6 \mathrm{~g}$ per kg; apigenin 7-O-b-D(6"-methylglucuronide, APG2, 1.1g per kg ) [9] might be developed industrially for its economic value. The quantity of apigenin present in the Limonium duriusculum could be used as biomarker in the industrial standardization and profiling of Limonium duriusculum, likely to $M$. chamomilla which has been considered a good source of apigenin [60]. Further investigations are necessary to fully elucidate the molecular mechanisms of action of BEL in several physiological processes in order to yield important insights into prophylactic and therapeutic applications.

Funding: The Algerian Ministry of High Teaching and Scientific Research for financial support; Department CIBIO, University of Trento, Italy.

Conflicts of Interest: The authors declare no conflict of interest.

\section{REFERENCES}

1. Souid A, Bellani L. Phytochemical and Biological Activities in Limonium Species Collected in Different Biotopes of Tunisia. 2019;16(7):e1900216.

2. Buyukbalci A, EI SN. Determination of in vitro antidiabetic effects, antioxidant activities and phenol contents of some herbal teas. Plant foods for human nutrition (Dordrecht, Netherlands). 2008;63(1):27-33.

3. Castroviejo S. Flora ibérica. Vol. III. Plumbaginaceae (partim)-Capparaceae: Editorial CSIC-CSIC Press; 2005.

4. Erben M. Bemerkungen zur taxonomie der Gattung Limonium VII. Sendtnera-Mitteilungen der Botanischen Staatssammlung und des Instituts fuer Systematische Botanik der Universitaet Muenchen. 2001;7:53-84.

5. Quézel P, Santa S. Nouvelle flore de l'Algérie et des régions désertiques méridionales: Éditions du Centre national de la Recherche scientifique; 1962.

6. Neill D, Romero C. Abrus Adans., Fam. PI. 2: 327. 1844.

7. Baillon H. Histoire des plantes: Hachette; 1869.

8. Kuntze O. Revisio generum plantarum vascularium omnium atque cellularium multarum secundum leges nomenclaturae internationales cum enumeratione plantarum exoticarum in itinere mundi collectarum: A. Felix; 1893.

9. Kerkatou M, Redouane-Salah A, León F, Brouard I, Mosset P, Menad A, et al. Secondary Metabolites and Antioxidant Activity of Limonium duriusculum (de Girard) Kuntze Extracts. Asian J. Chem. 2016;28(12):2695.

10. Hamadou MH, Kerkatou M, Gatto P, Pancher M, Bisio A, Inga A, et al. Apigenin rich-Limonium duriusculum (de Girard) Kuntze promotes apoptosis in HCT116 cancer cells. Nat. Prod. Res. 2019:1-5.

11. Karin M. How NF-kappaB is activated: the role of the IkappaB kinase (IKK) complex. Oncogene. 1999;18(49):686774.

12. Jonsson M, Jestoi M, Nathanail AV, Kokkonen UM, Anttila M, Koivisto P, et al. Application of OECD Guideline 423 in assessing the acute oral toxicity of moniliformin. Food and chemical toxicology : an international journal published for the British Industrial Biological Research Association. 2013;53:27-32.

13. Ohno M, Shibata C, Kishikawa T, Yoshikawa T, Takata A, Kojima K, et al. The flavonoid apigenin improves glucose tolerance through inhibition of microRNA maturation in miRNA103 transgenic mice. Sci Rep. 2013;3:2553.

14. Gradolatto A, Basly JP, Berges R, Teyssier C, Chagnon MC, Siess MH, et al. Pharmacokinetics and metabolism of apigenin in female and male rats after a single oral administration. Drug metabolism and disposition: the biological fate of chemicals. 2005;33(1):49-54.

15. Surana SS, Kumar RS. Anti-Inflammatory and Anti-Arthritic Activities of an Isolated Steroids Fraction (USM) of Stem Bark of Machilus macrantha Nees:(Lauraceae). Journal of The Analgesics. 2013;1(2):33-7.

16. Zhang F, Li F, Chen G. Neuroprotective effect of apigenin in rats after contusive spinal cord injury. Neurological sciences: official journal of the Italian Neurological Society and of the Italian Society of Clinical Neurophysiology. 2014;35(4):583-8.

17. Winter CA, Risley EA, Nuss GW. Carrageenin-induced edema in hind paw of the rat as an assay for antiiflammatory drugs. Proceedings of the Society for Experimental Biology and Medicine Society for Experimental Biology and Medicine (New York, NY). 1962;111:544-7.

18. Whittle BA. Release of a kinin by intraperitoneal injection of chemical agents in mice. Int. J. Neuropharmacol. 1964;3:369-78.

19. Brito GA, Souza MH, Melo-Filho AA, Hewlett EL, Lima AA, Flores CA, et al. Role of pertussis toxin A subunit in neutrophil migration and vascular permeability. Infect. Immun. 1997;65(3):1114-8. 
20. Bradley PP, Christensen RD, Rothstein G. Cellular and extracellular myeloperoxidase in pyogenic inflammation. Blood. 1982;60(3):618-22.

21. Bao W, Luo Y, Wang D, Li J, Wu X, Mei W. Sodium salicylate modulates inflammatory responses through AMPactivated protein kinase activation in LPS-stimulated THP-1 cells. J. Cell. Biochem. 2018;119(1):850-60.

22. Prasad S, Phromnoi K, Yadav VR, Chaturvedi MM, Aggarwal BB. Targeting inflammatory pathways by flavonoids for prevention and treatment of cancer. Planta Med. 2010;76(11):1044-63.

23. Mantovani A, Allavena P, Sica A, Balkwill F. Cancer-related inflammation. Nature. 2008;454(7203):436-44.

24. Klein U, Ghosh S. The Two Faces of NF-kB Signaling in Cancer Development and Therapy. Cancer cell. 2011;20(5):556-8.

25. Tak PP, Firestein GS. NF-kB: a key role in inflammatory diseases. J. Clin. Invest. 2001;107(1):7-11.

26. Verma I. Nuclear factor (NF)-kB proteins: therapeutic targets( $\left.{ }^{*}\right)$. Ann Rheum Dis. 2004;63(Suppl 2):ii57-61.

27. Lin Y, Bai L, Chen W, Xu S. The NF-kappaB activation pathways, emerging molecular targets for cancer prevention and therapy. Expert Opin Ther Targets. 2010;14(1):45-55.

28. Kim HJ, Hawke N, Baldwin AS. NF-[kappa]B and IKK as therapeutic targets in cancer. Cell Death Differ. 2006;13(5):738-47.

29. Zhang X, Wang G, Gurley EC, Zhou H. Flavonoid apigenin inhibits lipopolysaccharide-induced inflammatory response through multiple mechanisms in macrophages. PLoS One. 2014;9(9):e107072.

30. Muniandy K, Gothai S, Badran KMH, Suresh Kumar S, Esa NM. Suppression of Proinflammatory Cytokines and Mediators in LPS-Induced RAW 264.7 Macrophages by Stem Extract of Alternanthera sessilis via the Inhibition of the NF-kB Pathway. 2018;2018:3430684.

31. Nicholas C, Batra S, Vargo MA, Voss OH, Gavrilin MA, Wewers MD, et al. Apigenin blocks lipopolysaccharideinduced lethality in vivo and proinflammatory cytokines expression by inactivating NF-kappaB through the suppression of p65 phosphorylation. J Immunol (Baltimore, Md: 1950). 2007;179(10):7121-7.

32. Patil RH, Babu RL, Naveen Kumar M, Kiran Kumar KM, Hegde SM, Nagesh R, et al. Anti-Inflammatory Effect of Apigenin on LPS-Induced Pro-Inflammatory Mediators and AP-1 Factors in Human Lung Epithelial Cells. Inflammation. 2016;39(1):138-47.

33. Levy L. Carrageenan paw edema in the mouse. Life Sci. 1969;8(11):601-6.

34. Larsen GL, Henson PM. Mediators of inflammation. Annu Rev Immunol. 1983;1(1):335-59.

35. Di Rosa M, Giroud J, Willoughby D. Studies of the mediators of the acute inflammatory response induced in rats in different sites by carrageenan and turpentine. J Pathol. 1971;104(1):15-29.

36. Foster SJ, McCormick ME, Howarth A, Aked D. Leukocyte recruitment in the subcutaneous sponge implant model of acute inflammation in the rat is not mediated by leukotriene B1. Biochem Pharmacol. 1986;35(10):1709-17.

37. Ross JA, Kasum CM. Dietary flavonoids: bioavailability, metabolic effects, and safety. Annu Rev Nutr. 2002;22:1934.

38. El Shoubaky GA, Abdel-Daim MM, Mansour MH, Salem EA. Isolation and Identification of a Flavone Apigenin from Marine Red Alga Acanthophora spicifera with Antinociceptive and Anti-Inflammatory Activities. J. Exp. Neurosci. 2016;10:21-9.

39. Zhao L, Wang JL, Liu R, Li XX, Li JF, Zhang L. Neuroprotective, anti-amyloidogenic and neurotrophic effects of apigenin in an Alzheimer's disease mouse model. Molecules (Basel, Switzerland). 2013;18(8):9949-65.

40. Zheng QS, Sun XL, Xu B, Li G, Song M. Mechanisms of apigenin-7-glucoside as a hepatoprotective agent. Biomedical and environmental sciences: BES. 2005;18(1):65-70.

41. Liu R, Zhang T, Yang H, Lan X, Ying J, Du G. The flavonoid apigenin protects brain neurovascular coupling against amyloid-beta(2)(5)(-)(3)(5)-induced toxicity in mice. Journal of Alzheimer's disease: JAD. 2011;24(1):85-100.

42. Chakravarthi S, Wen CF, Haleagrahara N. Apoptosis and expression of bcl-2 in cyclosporine induced renal damage and its reversal by beneficial effects of 4', 5', 7'-trihydroxyflavone. J Anal Bio-Sci. 2009;32(4).

43. Shukla S, Gupta S. Molecular targets for apigenin-induced cell cycle arrest and apoptosis in prostate cancer cell xenograft. Mol. Cancer Ther. 2006;5(4):843-52.

44. Kim N-H, Sung SH, Heo J-D, Jeong EJ. The Extract of Limonium tetragonum Protected Liver against Acute Alcohol Toxicity by Enhancing Ethanol Metabolism and Antioxidant Enzyme Activities. 2015.

45. Tang X, Gao J, Chen J, Xu L, Tang Y, Dou H, et al. Expression of VDAC Regulated by Extracts of Limonium sinense Ktze root Against CCI(4)-induced Liver Damage. Int. J. Mol. Sci. 2007;8(3):204-13.

46. Alibabaei Z, Rabiei Z, Rahnama S, Mokhtari S, Rafieian-kopaei M. Matricaria Chamomilla extract demonstrates antioxidant properties against elevated rat brain oxidative status induced by amnestic dose of scopolamine. Biomed Aging Pathol. 2014;4(4):355-60.

47. Yoon JH, Baek SJ. Molecular targets of dietary polyphenols with anti-inflammatory properties. Yonsei Med J. 2005;46(5):585-96. 
48. Funakoshi-Tago M, Nakamura K, Tago K, Mashino T, Kasahara T. Anti-inflammatory activity of structurally related flavonoids, Apigenin, Luteolin and Fisetin. Int. Immunopharmacol. 2011;11(9):1150-9.

49. Sarkar FH, Li Y. Cell signaling pathways altered by natural chemopreventive agents. Mutat Res. 2004;555(1-2):5364.

50. González R, Ballester I, López-Posadas R, Suárez MD, Zarzuelo A, Martínez-Augustin O, et al. Effects of flavonoids and other polyphenols on inflammation. Crit Rev Food Sci Nutr. 2011;51(4):331-62.

51. Petkov E, Nikolov N, Uzunov P. Inhibitory effect of some flavonoids and falvonoid mixtures on cyclic AMP phosphodiesterase activity of rat heart. Planta Med. 1981;43(2):183-6.

52. Shukla S, Gupta S. Apigenin: A Promising Molecule for Cancer Prevention. Pharm Res. 2010;27(6):962-78.

53. Choi JS, Islam MN, Ali MY, Kim EJ, Kim YM, Jung HA. Effects of C-glycosylation on anti-diabetic, anti-Alzheimer's disease and anti-inflammatory potential of apigenin. Food and chemical toxicology: an international journal published for the British Industrial Biological Research Association. 2014;64:27-33.

54. Kowalczyk MC, Kowalczyk P, Tolstykh O, Hanausek M, Walaszek Z, Slaga TJ. Synergistic effects of combined phytochemicals and skin cancer prevention in SENCAR mice.Cancer Prev Res. (Philadelphia,Pa). 2010;3(2):1708.

55. During A, Debouche $\mathrm{C}$, Raas $\mathrm{T}$, Larondelle $\mathrm{Y}$. Among plant lignans, pinoresinol has the strongest antiinflammatory properties in human intestinal Caco-2 cells. J Nutr. 2012;142(10):1798-805.

56. Manach C, Williamson G, Morand C, Scalbert A, Remesy C. Bioavailability and bioefficacy of polyphenols in humans. I. Review of 97 bioavailability studies. Am.J. Clin. Nutr. 2005;81(1 Suppl):230s-42s.

57. Moroney MA, Alcaraz MJ, Forder RA, Carey F, Hoult JR. Selectivity of neutrophil 5-lipoxygenase and cyclooxygenase inhibition by an anti-inflammatory flavonoid glycoside and related aglycone flavonoids. J Pharm Pharmacol. 1988;40(11):787-92.

58. Lin YT, Hsiu SL, Hou YC, Chen HY, Chao PD. Degradation of flavonoid aglycones by rabbit, rat and human fecal flora. Biol Pharm Bull. 2003;26(5):747-51.

59. Chen T, Li LP, Lu XY, Jiang HD, Zeng S. Absorption and excretion of luteolin and apigenin in rats after oral administration of Chrysanthemum morifolium extract. J Agric Food Chem. 2007;55(2):273-7.

60. Smolinski AT, Pestka JJ. Modulation of lipopolysaccharide-induced proinflammatory cytokine production in vitro and in vivo by the herbal constituents apigenin (chamomile), ginsenoside $R b(1)$ (ginseng) and parthenolide (feverfew). Food and chemical toxicology: an international journal published for the British Industrial Biological Research Association. 2003;41(10):1381-90.

2021 by the authors. Submitted for possible open access publication under the terms and conditions of the Creative Commons Attribution (CC BY NC) license (https://creativecommons.org/licenses/by-nc/4.0/). 